\title{
Preimplantation Genetic Testing for Inherited Cancer Predisposition
}

\author{
Anver Kuliev*, Tatiana Pakhalchuk, Maria Prokhorovich and Svetlana Rechitsky \\ Reproductive Genetic Innovations, USA
}

*Corresponding author: Anver Kuliev, Reproductive Genetic Innovations, Chicago,

Illinois, USA.

Received Date: March 05, 2021

Published Date: March 23, 2021

\begin{abstract}
Summary
Inherited cancer predisposition is presently one of the major indications for preimplantation genetic testing (PGT), providing an option for couplers at risk to avoid the birth of an offspring with predisposition to cancer. We present here our experience of 874 PGT cycles for cancer, resulting in birth of 387 mutation free children, without risk of developing cancer, which is a part of our overall PGT series of 6,204 PGT cases for monogenic disorders (PGT-M), with 2,517 resulting births, free of genetic disorder. The accumulated experience demonstrates considerable progress in using PGT for avoiding the birth of children with genetic predisposition to cancer.
\end{abstract}

\section{Introduction}

There are no presently effective approaches to prevent the development of cancer in carries of cancer predisposing mutations, making preimplantation genetic testing (PGT) an attractive option for couples at risk to avoid the inheritance of cancer predisposing genes to their offspring [1-6]. The number of referrals for PGT of cancer has increased significantly after introduction of an expanding carrier screening, so the detected carries of cancer predisposing genes may now choose avoiding birth of a child with predisposition to varies cancers by utilizing PGT. Thus, the information on the practical utility of PGT for at risk couples should be available for couples with family history of cancer, so they could make their choices for carrier screening and PGT. Due to importance of such information for clinical practice, this paper will describe the present status of PGT for cancer predisposition, as a practical tool for avoiding the birth of children at risk for developing cancer, based on our experience since we performed the first case PGT for cancer in $1999[1,7,8]$.

\section{Material and Methods}

A series of 874 PGT cycles for 484 couples (Table 1) at risk for producing a progeny with mutations predisposing to cancer was performed (list of gene mutations predisposing to cancer, for which PGT was performed is presented in (Table 1).

The most frequent were breast cancer (284 PGT Cycles), neurofibromatosis type I and type II (102 PGT cycles), familial adenomatous polyposis 1 (FAP1) and colorectal cancer (94 PGT cycles), and Fanconi anaemia (FA) (83 PGT cycles), with PGT for other cancers performed in 34 cycles or less (see Table 1).

PGT cycles were performed using a standard IVF protocol, coupled with micromanipulation procedures of polar bodies (PB) or embryo biopsy, described in detail elsewhere [9]. Details of PGT guidelines were reported previously (10-11). The present standards of the procedure involve whole genome amplification (WGA) of biopsied PBs or embryos biopsy samples, followed by multiplex nested PCR analysis of the mutations in question, together with closely linked genetic markers in a multiplex heminested system. The majority of cases are currently performed by blastocyst biopsy followed by WGA [6,9]. For each family, heterozygous alleles and haplotypes not shared by parents were selected. This allowed detecting and avoiding misdiagnosis due to preferential amplification and allele dropout (ADO), and a possible 
aneuploidy or uniparental disomy of chromosomes in which the tested mutations are located, which may affect diagnostic accuracy of PGT. In PGT cycles, involving an advanced reproductive age of maternal partner, aneuploidy testing was also performed by next generation technologies (NGS) (Illumina Inc) for 24-chromosome aneuploidy testing [12].

\section{Results and Discussion}

Table 1 presents our cumulative experience of 874 PGT cycles performed for 484 couples at risk for producing offspring with genetic predisposition to cancer, caused by 56 different genes. This is the largest series available for PGT of cancer, resulting in transfer of 966 cancer predisposition free embryos in 634 cycles $(1.5$ average embryos per transfer), yielding 387 (61\%) clinical pregnancies and birth of 407 healthy children free of predisposing gene mutations and demonstrating the practical utility of PGT for cancer. The cancer predisposition, for which PGT has been performed, includes breast and ovarian cancer (BRCA I and II), Li-Fraumeni disease, Fanconi anaemia (FA), familial adenomatosis polyposis (FAP), familial colorectal cancer, hereditary nonpolyposis coli (HNPCC) (type 1 and 2), Von Hippel-Lindau syndrome (VHL), familial posterior fossa brain tumor (hSNF5), retinoblastoma (RB), neurofibromatosis 1 and 2 (NF1 and NF2), nevoid basal cell carcinoma (NBCCS) or Gorlin syndrome, tuberous sclerosis (TSC type 1 and type 2 ), ataxia telangiectasia, xeroderma pigmentosum-complimentary group G, exostosis multiple (EXT1 and EXT2), dyskeratosis congenital AD2/AD3/DKCX, gastric cancer, paragangliomas 5 (PGL5), PeutzJegher syndrome, multiple endocrine neoplasia (MEN 1/2A/4) and pleuropulmonary blastoma (see the complete list in Table 1).

Table 1: PGT for Cancer Predisposition in our overall PGT-M experience.

\begin{tabular}{|c|c|c|c|c|c|c|}
\hline Disease & Gene & \# Cycle & \# Transfers & \# Embryos Transferred & Pregnancy & Birth \\
\hline $\begin{array}{l}\text { ALBINISM, OCULOCUTANEOUS, } \\
\text { TYPE IA; OCA1A }\end{array}$ & TYR & 9 & 8 & 14 & 4 & 4 \\
\hline $\begin{array}{l}\text { ALBINISM, OCULOCUTANEOUS, } \\
\text { TYPE II; OCA2 }\end{array}$ & OCA2 & 4 & 3 & 6 & 2 & 2 \\
\hline $\begin{array}{l}\text { ALBINISM, OCULOCUTANEOUS, } \\
\text { TYPE III; OCA3 }\end{array}$ & TYRP1 & 1 & 0 & 0 & 0 & 0 \\
\hline ATAXIA-TELANGIECTASIA; AT & ATM & 10 & 6 & 10 & 5 & 4 \\
\hline $\begin{array}{l}\text { BASAL CELL NEVUS SYNDROME; } \\
\text { BCNS (Gorlin) }\end{array}$ & PTCH1 & 7 & 6 & 10 & 4 & 4 \\
\hline BIRT-HOGG-DUBE SYNDROME; BHD & FLCN & 2 & 1 & 1 & 1 & 1 \\
\hline $\begin{array}{l}\text { BREAST-OVARIAN CANCER, } \\
\text { FAMILIAL, SUSCEPTIBILITY TO, } 1 ; \\
\text { BROVCA1 }\end{array}$ & BRCA1 & 159 & 114 & 163 & 76 & 79 \\
\hline $\begin{array}{l}\text { BREAST-OVARIAN CANCER, } \\
\text { FAMILIAL, SUSCEPTIBILITY TO, 2; } \\
\text { BROVCA2 }\end{array}$ & BRCA2 & 125 & 85 & 117 & 55 & 55 \\
\hline $\begin{array}{l}\text { BREAST AND COLORECTAL CANCER, } \\
\text { SUSCEPTIBILITY }\end{array}$ & CHEK2 & 3 & 3 & 3 & 1 & 1 \\
\hline $\begin{array}{l}\text { COLORECTAL CANCER, HEREDITARY } \\
\text { NONPOLYPOSIS, TYPE 1; HNPCC1 } \\
\text { (LYNCH SYNDROME I) }\end{array}$ & MSH2 & 21 & 12 & 15 & 7 & 6 \\
\hline $\begin{array}{l}\text { COLORECTAL CANCER, HEREDITARY } \\
\text { NONPOLYPOSIS, TYPE 2; HNPCC2 }\end{array}$ & MLH1 & 18 & 15 & 25 & 9 & 10 \\
\hline $\begin{array}{l}\text { COLORECTAL CANCER, HEREDITARY } \\
\text { NONPOLYPOSIS, TYPE 4; HNPCC4 }\end{array}$ & PMS2 & 2 & 1 & 1 & 1 & 1 \\
\hline $\begin{array}{l}\text { COLORECTAL CANCER, HEREDITARY } \\
\text { NONPOLYPOSIS, TYPE 5; HNPCC5 }\end{array}$ & MSH6 & 11 & 9 & 11 & 5 & 5 \\
\hline $\begin{array}{l}\text { DYSKERATOSIS CONGENITA, AUTO- } \\
\text { SOMAL DOMINANT 3,DKCA3 }\end{array}$ & TINF2 & 1 & 1 & 1 & 1 & 1 \\
\hline $\begin{array}{l}\text { DYSKERATOSIS CONGENITA, AUTO- } \\
\text { SOMAL DOMINANT, 2, DKCA2 }\end{array}$ & TERT & 3 & 1 & 1 & 0 & 0 \\
\hline $\begin{array}{l}\text { DYSKERATOSIS CONGENITA, AUTO- } \\
\text { SOMAL RECESSIVE, 5, DKCB5 }\end{array}$ & RTEL1 & 1 & 1 & 1 & 1 & 1 \\
\hline $\begin{array}{l}\text { DYSKERATOSIS CONGENITA, } \\
\text { X-LINKED; DKCX }\end{array}$ & DKC1 & 1 & 1 & 2 & 1 & 1 \\
\hline $\begin{array}{l}\text { EPIDERMOLYSIS BULLOSA DYSTRO- } \\
\text { PHICA, AUTOSOMAL DOMINANT; } \\
\text { DDEB }\end{array}$ & COL7A1 & 9 & 8 & 10 & 4 & 4 \\
\hline
\end{tabular}




\begin{tabular}{|c|c|c|c|c|c|c|}
\hline $\begin{array}{l}\text { EPIDERMOLYSIS BULLOSA, JUNC- } \\
\text { TIONAL, HERLITZ TYPE }\end{array}$ & LAMA3 & 9 & 8 & 14 & 6 & 9 \\
\hline $\begin{array}{l}\text { EPIDERMOLYSIS BULLOSA, JUNC- } \\
\text { TIONAL, NON-HERLITZ TYPE }\end{array}$ & LAMB3 & 7 & 4 & 7 & 2 & 3 \\
\hline EXOSTOSES, MULTIPLE & EXT1, EXT2 & 29 & 22 & 38 & 15 & 16 \\
\hline $\begin{array}{l}\text { FAMILIAL ADENOMATOUS POLYPO- } \\
\text { SIS 1; FAP1 }\end{array}$ & APC & 42 & 31 & 51 & 14 & 13 \\
\hline $\begin{array}{l}\text { FANCONI ANEMIA, COMPLEMENTA- } \\
\text { TION GROUP A,C, D,E,D,F,J }\end{array}$ & FANC A,C,D,E,F,G,J & 83 & 45 & 71 & 20 & 22 \\
\hline $\begin{array}{l}\text { GASTRIC CANCER, HEREDITARY } \\
\text { DIFFUSE; HDGC }\end{array}$ & $\mathrm{CDH} 1$ & 1 & 1 & 2 & 1 & 2 \\
\hline $\begin{array}{l}\text { HEREDITARY LEIOMYOMATOSIS } \\
\text { AND RENAL CELL CANCER; HLRCC }\end{array}$ & $\mathrm{FH}$ & 2 & 2 & 2 & 1 & 1 \\
\hline $\begin{array}{c}\text { HERMANSKY-PUDLAK SYNDROME } \\
1 ; \text { HPS1 }\end{array}$ & HPS1 & 4 & 3 & 6 & 2 & 3 \\
\hline LI-FRAUMENI SYNDROME 1; LFS1 & TP53 & 22 & 17 & 24 & 13 & 11 \\
\hline $\begin{array}{l}\text { MULTIPLE ENDOCRINE NEOPLASIA, } \\
\text { TYPE I; MEN1 }\end{array}$ & MEN1 & 22 & 14 & 22 & 7 & 6 \\
\hline $\begin{array}{l}\text { MULTIPLE ENDOCRINE NEOPLASIA, } \\
\text { TYPE IIA; MEN2A }\end{array}$ & RET & 11 & 11 & 16 & 8 & 10 \\
\hline $\begin{array}{l}\text { MULTIPLE ENDOCRINE NEOPLASIA, } \\
\text { TYPE IV; MEN4 }\end{array}$ & CDKN1B & 3 & 1 & 1 & 1 & 1 \\
\hline $\begin{array}{l}\text { MYELODYSPLASTIC SYNDROME; } \\
\text { MDS }\end{array}$ & GATA2 & 1 & 1 & 1 & 1 & 1 \\
\hline NEUROFIBROMATOSIS, TYPE I; NF1 & NF1 & 93 & 79 & 121 & 46 & 46 \\
\hline NEUROFIBROMATOSIS, TYPE II; NF2 & NF2 & 10 & 9 & 17 & 7 & 9 \\
\hline $\begin{array}{l}\text { NIJMEGEN BREAKAGE SYNDROME; } \\
\text { NBS }\end{array}$ & NBN & 1 & 2 & 2 & 1 & 1 \\
\hline $\begin{array}{l}\text { PANCREATIC CANCER, SUSCEPTI- } \\
\text { BILITY TO, } 3\end{array}$ & PALB2 & 2 & 1 & 2 & 1 & 1 \\
\hline $\begin{array}{l}\text { PARAGANGLIOMA AND GASTRIC } \\
\text { STROMAL SARCOMA }\end{array}$ & SDHB & 3 & 2 & 2 & 1 & 1 \\
\hline PARAGANGLIOMAS 5; PGL5 & SDHA & 1 & 1 & 1 & 1 & 1 \\
\hline PEUTZ-JEGHERS SYNDROME; PJS & STK11 & 9 & 6 & 9 & 4 & 4 \\
\hline $\begin{array}{c}\text { PLATELET DISORDER, FAMILIAL, } \\
\text { WITH ASSOCIATED MYELOID MA- } \\
\text { LIGNANCY; FPDMM }\end{array}$ & RUNX1 & 1 & 1 & 1 & 1 & \\
\hline $\begin{array}{c}\text { PLEUROPULMONARY BLASTOMA; } \\
\text { PPB }\end{array}$ & DICER1 & 1 & 1 & 1 & 1 & 1 \\
\hline $\begin{array}{l}\text { RENAL CELL CARCINOMA, PAPIL- } \\
\text { LARY, 1; RCCP1 }\end{array}$ & MET & 1 & 2 & 2 & 1 & 1 \\
\hline RETINOBLASTOMA; RB1 & RB1 & 31 & 26 & 51 & 14 & 16 \\
\hline $\begin{array}{l}\text { RHABDOID TUMOR PREDISPOSI- } \\
\text { TION SYNDROME 1; RTPS1 }\end{array}$ & SMARCB1 & 1 & 1 & 1 & 1 & 0 \\
\hline $\begin{array}{l}\text { TELANGIECTASIA, HEREDITARY } \\
\text { HEMORRHAGIC, OF RENDU, OSLER, } \\
\text { AND WEBER; HHT }\end{array}$ & ENG & 11 & 6 & 7 & 3 & 2 \\
\hline $\begin{array}{l}\text { TELANGIECTASIA, HEREDITARY } \\
\text { HEMORRHAGIC, TYPE 2; HHT2 }\end{array}$ & ACVRL1 & 8 & 4 & 6 & 2 & 2 \\
\hline TUBEROUS SCLEROSIS 1; TSC1 & TSC1 & 30 & 25 & 49 & 16 & 23 \\
\hline TUBEROUS SCLEROSIS 2; TSC2 & TSC2 & 14 & 8 & 12 & 4 & 4 \\
\hline $\begin{array}{c}\text { VON HIPPEL-LINDAU SYNDROME; } \\
\text { VHL }\end{array}$ & VHL & 25 & 16 & 25 & 10 & 11 \\
\hline $\begin{array}{l}\text { XERODERMA PIGMENTOSUM, COM- } \\
\text { PLEMENTATION GROUP G; XPG }\end{array}$ & ERCC5 & 2 & 1 & 1 & 1 & 1 \\
\hline TOTAL PGT for Cancer & 56 GENES & 874 & 634 & $966(1.52)$ & $387(61 \%)$ & 407 \\
\hline TOTAL PGT-M Experience & 558 GENES & 6204 & 4630 & $7061(1.52)$ & $2447(52.8 \%)$ & 2517 \\
\hline
\end{tabular}


As mentioned, the most frequent indications for PGT were BRCA I and II. Of 284 PGT cycles performed for breast cancer, 280 embryos free of predisposing gene were detected for transfer in 199 cycles, resulting in birth of 134 children with no risk to develop breast cancer predisposed by these genes in their lifespan. Another most common indication for PGT was NF I and NF II, an autosomaldominant cancer caused by different mutations in the NFI and NFII genes. Of 102 PGT cycles performed for NF, 137 predisposition free embryos were selected for transfer in 87 cycles, resulting in birth of 54 children free from the risk of developing NF in their lifespan. The other large groups included FA (83 PGT cycles) and colorectal cancer (52 PGT cycles), resulting in birth of 44 children free from inherited predisposition to these cancers. As seen from Table 1, children with no risk to develop cancer in their lifespan was born in all but one PGT indications, suggesting a practical utility of PGT for cancer. Table 1 also presents our overall PGT experience for Mendelian disorders, comprising 558 different conditions, with the most frequent ones shifting from traditional single gene disorders to common conditions with genetic predisposition, such as cancer. As mentioned, risk of having offspring with severe lateonset common disorders caused by strong genetic predisposition is increasingly accepted indication for PGT-M. It is of note that the PGT referral spectrum has also changed, with current shift to direct referral through expanded carrier screening [13]. The reason of preference of PGT for genetic predisposition to common conditions, including cancer, in contrast to prenatal diagnosis is obvious, as prenatal diagnosis could lead to pregnancy termination that is not justified on the basis of genetic predisposition alone. On the other hand, choosing the embryos free of genetic predisposition to cancer would obviate the need for considering pregnancy termination, as only potentially normal pregnancies are established. PGT for cancer gained acceptability also on ethical grounds, because only a limited number of the embryos (presently only one) is selected for transfer. This may explain why the number of PGT requests for inherited predisposition for common late onset conditions, such as cancer, has been increasing overall. One of other possible reasons to request PGT for inherited cancer is that it may manifest even after surgery, such as in breast cancer, with PGT providing the only alternative for some at-risk couples to reproduce and avoid clinical termination of an affected fetus.

With accelerating progress in understanding the molecular basis of cancers, inherited cancer predispositions are becoming the major emerging PGT indication. Most of them are dominant and may be also secondary to germline mutations. A strong predisposition to many cancers is also determined by tumor suppressor genes, a major factor for genetic instability [14]. As seen from Table 1, cancer predisposition account already for $14 \%$ of all PGT-M cases, despite still remaining controversy, because cancers may present beyond early childhood and may even not be expressed in $100 \%$ of the cases. Despite extensive discussions of the ethical and legal issues involved in PGT for late-onset disorders with genetic predisposition, an increasing number of patients clearly regard the procedure not only as their preferable option but the only possible reason for forgoing the pregnancy $[6,15,16]$. Genetic counseling and oncologic services should inform patients at risk for these cancers that having children with genetic predisposition to cancers can be avoided through PGT. Options exist for couples who might have chosen to remain childless because of their concern to avoid prenatal diagnosis and possible pregnancy termination.

Presented results show that PGT is a realistic option for couples at risk for producing offspring at risk for developing cancer. In fact, the family history may alone provide the reason to test for presence of predisposing gene mutations to cancer and the need for PGT. This may be a life-saving procedure for the offspring of individuals carrying cancer predisposing genes. With future advances in identification of genes predisposing to inherited cancer, PGT might appear as a useful tool for couples at risk for producing offspring with inherited cancer.

\section{Acknowledgement}

None.

\section{Conflict of Interest}

No conflict of interest

\section{References}

1. Verlinsky Y, Rechitsky S, Verlinsky O, Kangu X, Glenn S, et al. (2001) Preimplantation diagnosis for p53 tumor suppressor gene mutations. Reprod Biomed Online 2(2): 102-105.

2. Rechitsky S, Verlinsky O, Chistokhina A, Tatyana S, Seckin O, et al. (2002) Preimplantation genetic diagnosis for cancer predisposition. Reprod Biomed Online 4: 148-155.

3. Jasper MJ, Liebelt J, Hussey ND (2007) Preimplantation genetic diagnosis for cancer predisposition syndromes. Prenat Diagn 27:447-456.

4. Jasper MJ, Liebelt J, Hussey ND (2008) Preimplantation genetic diagnosis for BRCA1 exon 13 duplication mutation using linked polymorphic markers resulting in a live birth. Prenat Diagn 28(4) :292-298.

5. Moutou C, Gardes N, Nicod JC, Viville S (2009) Preimplantation genetic diagnosis for BRCA1/2 - a novel clinical experience. Eur J Obstet Gynecol Reprod Biol 45: 9-13.

6. Kuliev A, Rechitsky S, Simpson JL (2020) Practical Preimplantation Genetic Testing. Third Edition. Springer Nature Switzerland.

7. Simpson JL (2001) Celebrating preimplantation genetic diagnosis of p53 mutations in Li-Fraumeni syndrome. Reprod Biomed Online 3(1): 2-3.

8. Cram D (2001) Preimplantation genetic diagnosis for familial cancer. Reprod Biomed Online 3(1): 3-4

9. Kuliev A, Rechitsky S, Verlinsky O (2014) Atlas of Preimplantation Genetic Diagnosis. An Illustrated Textbook. Third Edition. Taylor \& Francis. London.

10. Preimplantation Genetic Diagnosis International Society (PGDIS) (2008) Guidelines for good practice in PGD: program requirements and laboratory quality assurance. Reprod BioMed Online 16(1): 134-147

11. Filipa C, Edith C, Veerle G, Georgia K, Carmen R, et al. (2020) ESHRE PGT Consortium good practice recommendations for the organization of PGT. Human Reprod Open 2020(3): hoaa021. 
12. Rechitsky S, Pakhalchuk T, Goodman A, San-Ramos J, Zlatopolsky Z, et al. (2015) First systematic experience of combined PGD for single gene disorders and/or Preimplantation HLA typing with 24-chromosome aneuploidy testing, Fertility \& Sterility 103(2): 503-512

13. Simpson JL, Rechitsky S, Kuliev A (2019) Before the beginning: the genetic risk of a couple aiming to conceive. Fertil Steril 112 (4): 622-630

14. Donehower L, Soussi S, Korkut A (2019) Integrated Analysis of TP53 Gene and Pathway Alterations in the Cancer Genome Atlas Cell Rep 28(5): 1370-1384.
15. Vadaparampil ST, Quinn GP, Knapp C, Malo TL, Friedman S (2009) Factors associated with preimplantation genetic diagnosis acceptance among women concerned about hereditary breast and ovarian cancer. Genet Med 11(10): 757-765.

16. Quinn GP, Vadaparampil ST, King LM, Miree CA, Friedman S (2009) Familial cancer Conflict between values and technology: perceptions of preimplantation genetic diagnosis among women at increased risk for hereditary breast and ovarian cancer. Fam Cancer 8(4): 441- 449. 